\title{
Synergistic effect of glucose and prolactin on GLUT2 expression in cultured neonatal rat islets
}

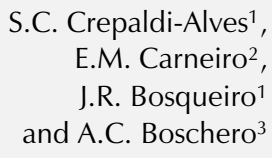

\author{
${ }^{1}$ Departamento de Educação Física/Ciências Biológicas, \\ Universidade Estadual Paulista, 17033-360 Bauru, SP, Brasil \\ ${ }^{2}$ Departamento de Educação Física, Instituto de Biociências, \\ Universidade Estadual Paulista, 13506-900 Rio Claro, SP, Brasil \\ ${ }^{3}$ Departamento de Fisiologia e Biofísica, Instituto de Biologia, \\ Universidade Estadual de Campinas, 13083-970 Campinas, SP, Brasil
}

\section{Correspondence \\ A.C. Boschero \\ Departamento de Fisiologia e \\ Biofísica \\ Instituto de Biologia, UNICAMP \\ 13083-970 Campinas, SP \\ Brasil \\ Fax: 55 (019) 239-3124 \\ Research supported in part by CNPq and FAPESP.}

Received October 1, 1996 Accepted December 17, 1996

\begin{abstract}
We studied the synergistic effect of glucose and prolactin (PRL) on insulin secretion and GLUT2 expression in cultured neonatal rat islets. After 7 days in culture, basal insulin secretion $(2.8 \mathrm{mM}$ glucose $)$ was similar in control and PRL-treated islets $(1.84 \pm 0.06 \%$ and $2.08 \pm$ $0.07 \%$ of the islet insulin content, respectively). At 5.6 and $22 \mathrm{mM}$ glucose, insulin secretion was significantly higher in PRL-treated than in control islets, achieving $1.38 \pm 0.15 \%$ and $3.09 \pm 0.21 \%$ of the islet insulin content in control and $2.43 \pm 0.16 \%$ and $4.31 \pm 0.24 \%$ of the islet insulin content in PRL-treated islets, respectively. The expression of the glucose transporter GLUT2 in B-cell membranes was dosedependently increased by exposure of the islet to increasing glucose concentrations. This effect was potentiated in islets cultured for 7 days in the presence of $2 \mu \mathrm{g} / \mathrm{ml}$ PRL. At 5.6 and $10 \mathrm{mM}$ glucose, the increase in GLUT2 expression in PRL-treated islets was 75\% and $150 \%$ higher than that registered in the respective control. The data presented here indicate that insulin secretion, induced by different concentrations of glucose, correlates well with the expression of the B-cell-specific glucose transporter GLUT2 in pancreatic islets.
\end{abstract}

The first step in glucose-induced insulin secretion is the entry of the sugar into the Bcells, which is mediated by the glucose transporter GLUT2, located on the B-cell plasma membrane. Alteration in the expression of GLUT2 has been implicated in the reduction of the secretory response to glucose $(1,2)$. Since growth and differentiation of the endocrine pancreas are controlled by glucose and the somatolactogenic hormones, growth hormone (GH) and prolactin (PRL) (3), we determined the effect of glucose on insulin
Key words

- Pancreatic islets

- Glucose transporter

- Prolactin

- Glucose secretion and GLUT2 expression in neonatal rat islets cultured in the presence or absence of PRL.

We have used islets from neonatal rats (2 to $48 \mathrm{~h}$ old) obtained by collagenase digestion and cultured for 7 days, as described previously (4). After 7 days, the culture medium was discarded and the islets were incubated for $90 \mathrm{~min}$ at $37^{\circ} \mathrm{C}$ in a bicarbonatebuffered solution containing different concentrations of glucose. The supernatant was withdrawn for insulin measurements and the 
insulin present in the islets was extracted with $1 \mathrm{ml}$ acid-ethanol. Insulin was measured by standard radioimmunoassay (5), and is reported as percent of the total islet content. For Western blot analysis, groups of approximately 1000 islets $(\mathrm{N}=4)$ were homogenized in Tris- $\mathrm{HCl}$ buffer containing 1 $\mathrm{mM}$ EDTA, $1-2 \mu \mathrm{g} / \mathrm{ml}$ antipain, $1 \mu \mathrm{g} / \mathrm{ml}$ pepstatin, $1 \mathrm{mM}$ benzamidine, $1-2 \mu \mathrm{g} / \mathrm{ml}$ aprotinin, $100 \mu \mathrm{g} / \mathrm{ml}$ phenylmethylsulfonyl fluoride, and $0.02 \%$ Tween 20 . The protein content of the homogenates was measured by the BioRad protein assay (BioRad Lab., Melville, NY). Aliquots containing $50 \mu \mathrm{g}$ of protein were submitted to electrophoresis on a 10\% SDS-polyacrylamide gel and transferred onto nitrocellulose membranes (BioRad). The membranes were blocked with $4 \%$ defatted dry milk, and $0.2 \%$ Tween 20 in Tris-buffered saline, $\mathrm{pH} 7.4$, for $2 \mathrm{~h}$ at $20^{\circ} \mathrm{C}$. These membranes were then incubated with a polyclonal rabbit antiserum against GLUT2 (1:1000) (East Acres, Southbridge, MA), and washed with Tris-buffered saline and the antibody-antigen complex was detected by incubation with a rabbit $\operatorname{Ig}^{125}$ I-labeled whole antibody from donkey (Amersham, UK).

After 7 days in culture, basal insulin secretion ( $2.8 \mathrm{mM}$ glucose) was similar in control and PRL-treated islets, achieving 1.84 $\pm 0.06 \%(\mathrm{~N}=21)$ and $2.08 \pm 0.07 \%(\mathrm{~N}=21)$ of the islet insulin content, respectively, in $90 \mathrm{~min}$. At threshold glucose concentrations $(5.6 \mathrm{mM})$, insulin secretion was $1.38 \pm 0.15 \%$ $(\mathrm{N}=12)$ and $2.43 \pm 0.16 \%(\mathrm{~N}=12)$ of the islet insulin content $(\mathrm{P}<0.05)$ in 90 min for control and PRL-treated islets, respectively. In the presence of $22 \mathrm{mM}$ glucose, insulin secretion was $3.09 \pm 0.21 \%$ and $4.31 \pm 0.24 \%$ of islet content for control and PRL-treated islets, respectively $(\mathrm{P}<0.05)$. The presence of GLUT2 in the B-cell plasma membrane of neonatal cultured islets (Figure 1) was demonstrated by immunohistochemistry (6). Interestingly, a positive reaction to the GLUT2 antibody was also detected as bright dots inside the B-cell cytoplasm, suggesting the presence of glucose transporters in membranes of internal organelles. At present we have no explanation for this finding. Immu-

Figure 1 - Immunolocalization of the glucose transporter GLUT2 in the plasma membrane of Bcells from cultured neonatal rat islets. The presence of GLUT2 was revealed in sections $(10 \mu \mathrm{m})$ of rat islets by indirect immunofluorescence using a polyclonal rabbit GLUT2 antiserum (dilution 1:1000) and a fluorescein isothiocyanate (FITC)-conjugated specific second antibody (dilution 1:100). Fluorescence was detected by confocal laser scanning microscopy. Note the bright reaction at the cell membrane level following GLUT2 immunolocalization (arrow).

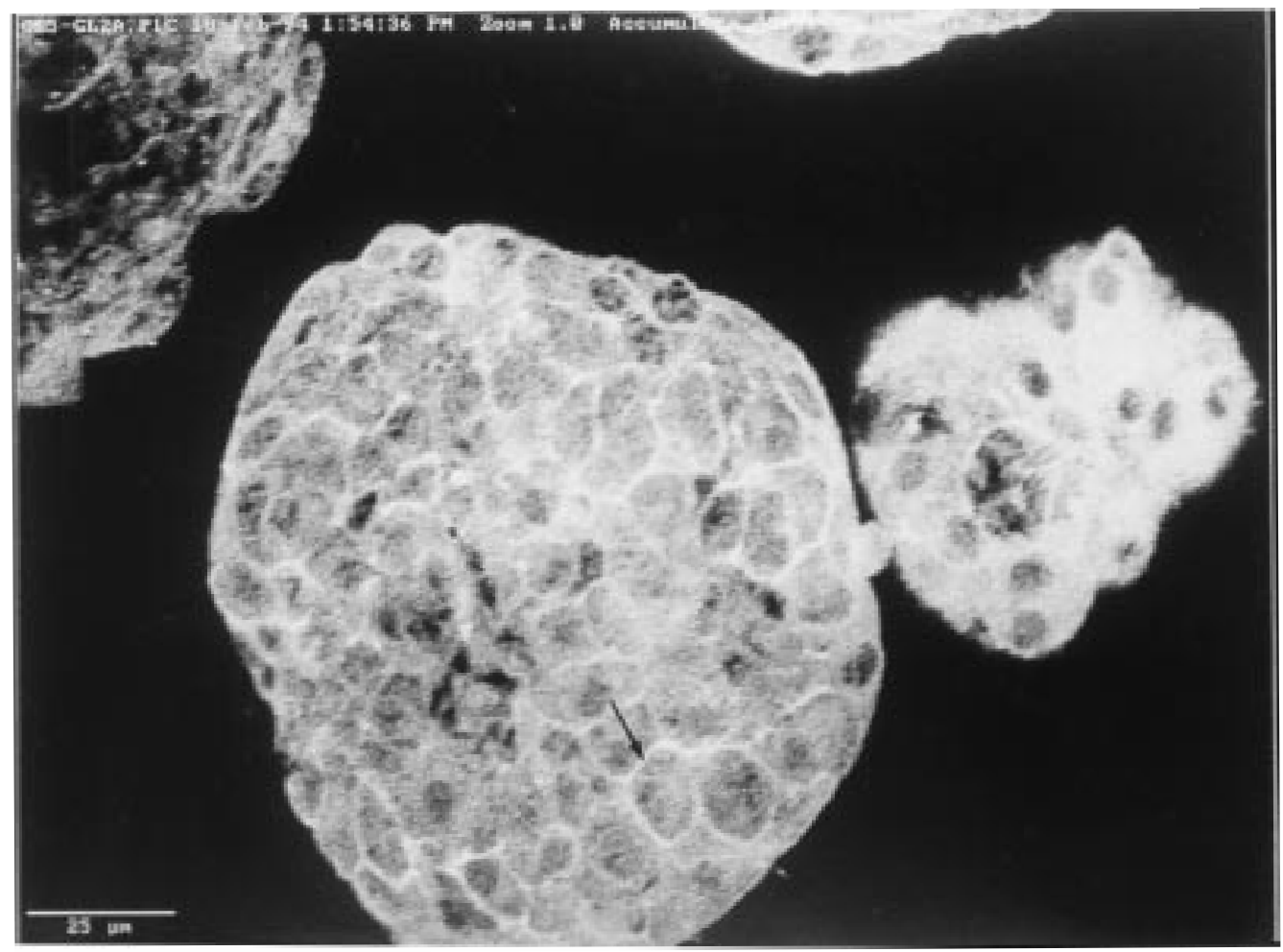




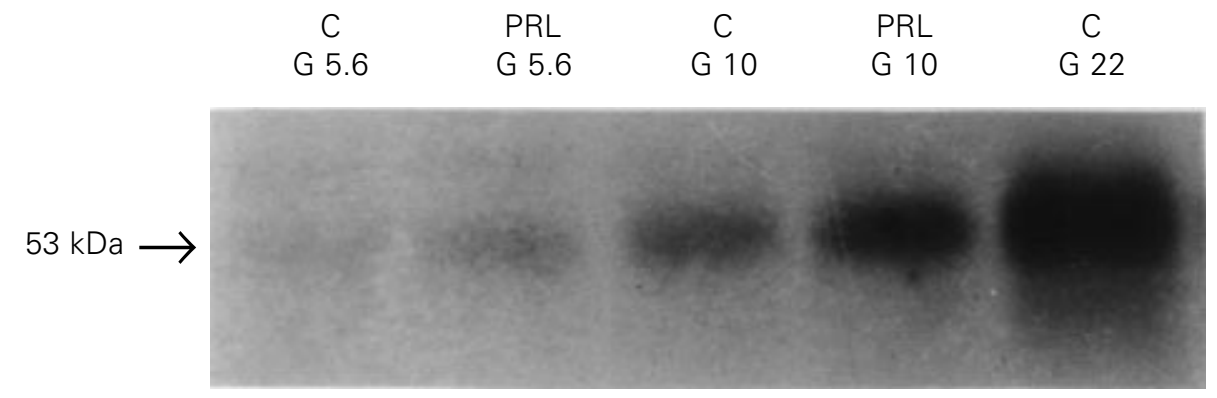

noblot analysis of neonatal islets with an antibody specific for the liver B-cell glucose transporter GLUT2 is shown in Figure 2. The antibody labeled a 53-kDa band corresponding to GLUT2 in both control and PRL-treated islets. PRL treatment increased the GLUT2 content of the islets by approximately $75 \%$ and $150 \%$ in the presence of 5.6 and $10 \mathrm{mM}$ glucose, respectively (measurements made by densitometry and by radioactivity analysis). A high concentration of glucose $(22 \mathrm{mM})$ alone also increased the GLUT2 content of the islets by about 8 times as compared to control values $(5.6 \mathrm{mM}$ glucose).

These data confirm prior observations that PRL treatment increases GLUT2 ex- pression in pancreatic B-cells $(7,8)$. Expression of GLUT2 was further enhanced with the combination of glucose and PRL. The synergistic effect of glucose and PRL treatment on GLUT2 expression correlates well with the increased insulin secretion provoked by glucose in PRL-treated islets compared to control islets (9). These observations indicate that GLUT2 may play an important role in the process of maturation of the glucosesensing mechanism in neonatal islets.

\section{Acknowledgment}

We thank Dr. Carla Collares-Buzato for help and suggestions.
Figure 2 - Effect of glucose and prolactin (PRL) treatment on GLUT2 protein content measured by immunoblotting. Neonatal rat islets were cultured for 7 days in medium containing or not $2 \mu \mathrm{g} / \mathrm{ml} \mathrm{PRL}$ and glucose at different concentrations. Neonatal islet protein $(50 \mu \mathrm{g} / \mathrm{lane})$ was analyzed by immunoblotting with antiserum to GLUT2. This is a representative blot of two.

\section{References}

1. Johnson JH, Ogawa A, Chen L, Orci L, Newgard CB, Alam T \& Unger RH (1990). Underexpression of B-cell high $\mathrm{Km}$ glucose transporters in non-insulin-dependent diabetes. Science, 250: 546-549.

2. Unger RH (1991). Diabetic hyperglycemia: link to impaired glucose transporter in pancreatic B cells. Science, 251: 12001205.

3. Nielsen $\mathrm{JH}$, Billestrup $\mathrm{N}$, Moldrup $\mathrm{A}$, Allevato G, Petersen ED, Amstrup J \& Hansen JA (1993). Growth of the endocrine pancreas: the role of somatolactogenic hormones and receptors. Biochemical Society Transactions, 21: 146-149.

4. Boschero AC, Crepaldi SC, Carneiro EM, Delattre E \& Atwater I (1993). Prolactin induces maturation of glucose sensing mechanisms of cultured neonatal rat islets. Endocrinology, 133: 515-520.
5. Scott AM, Atwater I \& Rojas E (1981). A method for the simultaneous measurement of insulin release and B-cell membrane potential in single mouse islets of Langerhans. Diabetologia, 21: 470-475

6. Saez JC, Berthoud VM, Kadle R, Traub O, Nicholson BJ, Bennet MVL \& Dermietzel R (1991). Pinealocytes in rats: connexin identification and increase in coupling caused by norepinephrine. Brain Research, 568: 265-275.

7. Mazancourt P, Carneiro EM, Atwater I \& Boschero AC (1994). Prolactin treatment increases GLUT2 but not the G protein subunit content in cell membranes from cultured neonatal rat islets. FEBS Letters, 343: 137-140.
8. Weinhaus AJ, Stout LE \& Sorenson RL (1996). Glucokinase, hexokinase, glucose transporter 2, and glucose metabolism in islets during pregnancy and prolactintreated islets in vitro: mechanism for long term up-regulation of islets. Endocrinology, 137: 1640-1649.

9. Crepaldi SC, Carneiro EM \& Boschero AC (1996). Long-term effect of prolactin (PRL) treatment on glucose-induced insulin secretion in cultured neonatal rat islets. Hormone and Metabolic Research (in press). 